\title{
Diversifikasi Produk Olahan Pangan Hasil Aplikasi Vertikultur Tanaman Sayuran di Kelurahan Tengah, Kramat Jati, Jakarta Timur
}

\section{(Diversification of Food from Verticulture Applications of Vegetable Plants in Tengah Village, Kramat Jati, East Jakarta)}

\author{
Julfi Restu Amelia ${ }^{1 *}$, Ira Mulyawati ${ }^{2}$, Lisa Ratnasari ${ }^{3}$ \\ ${ }^{1}$ Jurusan Teknologi Pangan, Fakultas Teknologi Pangan dan Kesehatan, Universitas Sahid Jakarta, Jl. Prof. DR. Soepomo \\ No.84, RT.7/RW.1, Menteng Dalam, Tebet, Jakarta Selatan 12870. \\ 2 Jurusan Teknik Lingkungan Fakultas Teknik, Universitas Sahid Jakarta, Jl. Prof. DR. Soepomo No.84, RT.7/RW.1, \\ Menteng Dalam, Tebet, Jakarta Selatan 12870. \\ 3 Jurusan Teknik Industri, Fakultas Teknik, Universitas Sahid Jakarta Jl. Prof. DR. Soepomo No.84, RT.7/RW.1, \\ Menteng Dalam, Tebet, Jakarta Selatan 12870. \\ *Penulis Korespondensi: fiamel2702@gmail.com \\ Diterima November 2018/Disetujui Juni 2018
}

\begin{abstract}
ABSTRAK
Pemanfaatan lahan pekarangan pada saat ini masih belum optimal, sehingga pengembangan berbagai inovasi yang terkait dengan lahan pekarangan juga terbatas. Hal tersebut terjadi karena lahan pekarangan yang dimiliki masyarakat pada umumnya sangat sempit, namun hal tersebut dapat diatasi dengan teknik vertikultur. Permasalahan yang dihadapi adalah menurunnya minat dan partisipasi mitra dan masyarakat kelurahan Tengah dalam melakukan kegiatan penghijauan di lingkungan karena keterbatasan lahan dan dalam pengembangan produk-produk olahan pertanian karena kesulitan bahan baku serta keterbatasan pemasaran produk. Tujuan dari kegiatan adalah peningkatan partisipasi mitra dan masyarakat Kelurahan Tengah, Jakarta Timur melalui pendampingan dalam optimalisasi penghijauan lingkungan, pengolahan produk pangan, dan pengembangan sistem pemasaran melalui pemasaran online. Metode yang dilakukan berupa metode pendekatan, pendampingan, sosialisasi, dan pelatihan/bimbingan teknis, berupa pelatihan/pendampingan paket teknologi penghijauan (menggunakan pipa talang air berbentuk persegi panjang yang disusun secara vertikal (vertikultur); bimbingan teknis pengolahan pangan berupa minuman bayam wortel nanas (Batelnas), minuman okra madu jahe (The Kraduu), dodol jahe wijen (Dojawi), dan dodol jahe wortel (Dojawo); serta pelatihan/ pendampingan berupa teknik pemasaran produk pangan yang dihasilkan secara digital. Hasil kegiatan menunjukkan bahwa melalui transfer teknologi tepat guna dan pendampingan kepada mitra dan masyarakat sasaran mampu menarik kembali minat dan partisipasi untuk lebih peduli pada lingkungan serta membuka peluang usaha dari kegiatan tersebut. Produk yang dihasilkan dari kegiatan ini berupa inovasi baru sehingga mempunyai nilai tambah ekonomi sehingga apabila dilakukan secara kontinu dapat menambah pendapatan rumah tangga bagi mitra dan masyarakat sasaran.
\end{abstract}

Kata kunci: diversifikasi, olahan pangan, pemasaran online, teknologi tepat guna, vertikultur

\begin{abstract}
Utilization of garden area at this time is still not optimal, and the development of various innovations related to the garden area is also limited. This fact related with the garden that owned by the people in general is very narrow. Verticulture is one of technique that can be used for narrow land in urban farming. The target audience of the activity is the partners and the community of Kelurahan Tengah, East Jakarta. The problems that exist are decreasing in interest and participation of target audience in carrying out reforestation activities due to limited land, and in the development of processed food products that is related with the difficulty of raw materials and the limitations of product marketing. The aim of the activity is to increase the participation of target audiences through assistance in optimizing reforestation activities, processing food products and developing market systems through online marketing. The method used in the activity are approach, socialization, and training, such as training on greening technology packages (verticulture techniques); food processing training: drinks from spinach, carrot and pineapple (Batelnas), drinks from okra, honey and ginger (The Kraduu), dodol from ginger and sesame (Dojawi), and dodol from ginger and carrot (Dojawo); and digital marketing technique training. The results showed that activity through appropriate technology transfer and assistance to the target audience is able to increase interest and participation and better care for the environment as well as business opportunities from such activities. The products resulted from this activity are new innovation products so that
\end{abstract}


they have economic added value, and if it continuously done, it will increase household income of the target audience.

Keywords: appropriate technology, food processing, online marketing, verticulture

\section{PENDAHULUAN}

Permintaan sayuran organik dan produkproduk olahan pangan bernutrisi semakin lama semakin meningkat seiring dengan adanya pola hidup sehat di masyarakat. Dengan semakin meningkatnya kebutuhan tersebut maka diperlukan upaya-upaya ke arah peningkatan produksi, salah satunya dengan pemanfaatan tanaman pekarangan. Pemanfaatan tanaman pekarangan dapat dijadikan lahan usaha tani yang efektif untuk mendukung program peningkatan produksi dan ketahanan pangan keluarga di perkotaan maupun di perdesaan (Mardiyanto 2009). Pada kenyataannya berdasarkan hasil kajian badan litbang pertanian, sebagaimana dilaporkan oleh Mardiharini (2011) dikemukakan bahwa pemanfaatan lahan pekarangan masih sangat terbatas, sehingga pengembangan berbagai inovasi yang terkait dengan lahan pekarangan juga sangat terbatas, padahal pemanfaaatan lahan pekarangan untuk tanaman pangan, hortikultura, dan tanaman rempah dapat memenuhi kebutuhan masyarakat. Selain itu, pemanfaatan lahan pekarangan sebagai media tanam sayuran dapat menambah pendapatan masyarakat apabila sayur-sayuran yang dihasilkan diolah menjadi produk pangan yang bernilai ekonomis. Salah satu daerah yang belum melaksanakan hal tersebut adalah Kelurahan Tengah, Kramat Jati, Jakarta Timur. Lahan pekarangan yang sempit menjadi salah satu alasan bagi masyarakat di Kelurahan Tengah belum melaksanakan hal tersebut. Salah satu cara yang dapat dikembangkan untuk penanaman sayuran di lahan pekarangan sempit adalah dengan teknik vertikultur. Berdasarkan hal-hal tersebut di atas, tim pengabdian masyarakat melaksanakan kegiatan progam diversifikasi produk olahan pangan hasil aplikasi vertikultur tanaman sayuran di Kelurahan Tengah, Kramat Jati, Jakarta timur.

Khalayak sasaran dari kegiatan diversifikasi produk olahan pangan hasil aplikasi vertikultur tanaman sayuran, yakni masyarakat Kelurahan Tengah bekerja sama dengan salah satu tokoh masyarakat yang berada di Kelurahan Tengah $(\mathrm{H}$ Ramin sebagai mitra 1 dan Ibu PKK yang diwakili oleh Ibu Titi sebagai mitra 2). Khalayak sasaran (mitra dan masyarakat) pada awalnya telah memiliki kegiatan berupa pengolahan sampah kulit bawang menjadi kompos, di mana kompos yang dihasilkan dimanfaatkan oleh masyarakat untuk digunakan sebagai media tanam. Namun, pelaksanaan kegiatan tersebut mengalami kendala karena menurunnya partisipasi dan minat warga sekitar dalam melaksanakan kegiatan tersebut secara bersama-sama. Saat ini, pengelolaan sampah hanya dilakukan secara individu oleh salah satu mitra (H. Ramin). Mitra tersebut hanya fokus dalam pembuatan pupuk kompos yang kemudian hanya mampu dikomersialisasikan dalam skala kecil. Belum ada keinginan dan kegiatan masif dari masyarakat yang berusaha memanfaatkan kembali pupuk kompos organik tersebut untuk diaplikasikan dalam kegiatan seperti budi daya sayur, buahbuahan, atau rempah skala rumah tangga. Selain itu, penurunan minat masyarakat juga disebabkan kebingungan masyarakat dalam mengaplikasikan kompos tersebut karena lahan pekarangan yang mereka miliki sangat terbatas. Masyarakat Kelurahan Tengah, juga pada awalnya telah melakukan pengolahan pangan menjadi beberapa produk makanan seperti dodol. Namun, pada saat ini kegiatan-kegiatan tersebut tidak dilaksanakan kembali yang disebabkan adanya penurunan minat serta partisipasi masyarakat, sehingga kegiatan tersebut menjadi terhenti. Penurunan minat masyarakat tersebut disebabkan karena kesulitan bahan baku serta keterbatasan pemasaran produk.

Salah satu solusi permasalahan-permasalahan tersebut adalah dengan memanfaatkan lahan pekarangan masyarakat yang terbatas dengan menanam tanaman sayuran bernilai ekonomis dengan menggunakan teknik vertikultur. Teknik penanaman vertikultur merupakan salah satu teknik penanaman yang dapat dilakukan baik indoor maupun outdoor, karena kepemilikan lahan terbatas yang dirancang sedemikian rupa sehingga berposisi vertikal atau bertingkat. Tanaman yang dibudidayakan pada umumnya merupakan tanaman yang memiliki nilai ekonomis tinggi, berumur pendek, atau tanaman semusim. Tanaman sayuran pekarangan dari hasil verikultur kemudian dapat diolah menjadi menjadi produk olahan pangan bernilai ekonomis, seperti makanan dan minuman kesehatan. 
Produk olahan bernilai ekonomis tersebut kemudian dapat dikomersialkan dengan menggunakan teknik pemasaran yang efektif sehingga dapat menjadi sumber pendapatan rumah tangga, serta dapat meningkatkan kemandirian ekonomi masyarakat, yang secara tidak langsung dapat meningkatkan kembali minat masyarakat.

Secara umum yang menjadi tujuan dan sasaran yang ingin dicapai dalam kegiatan pengabdian masyarakat bagi mitra dan masyarakat adalah peningkatan partisipasi khalayak sasaran Kelurahan Tengah, Kramat Jati melalui pendampingan dalam optimalisasi penghijauan lingkungan, pengembangan sejumlah produk pangan dan pengembangan sistem pemasaran melalui pemasaran online. Tujuan dan sasaran tersebut dapat dirinci sebagai berikut: mitra yang merupakan warga RW 10 Kelurahan Tengah, Jakarta Timur mendapatkan pendampingan dalam hal: a) Sosialisasi untuk memotivasi sumber daya; b) Optimalisasi penghijauan lingkungan menggunakan pupuk kompos dengan teknik penanaman menggunakan pipa talang air berbentuk persegi panjang yang disusun secara vertikal; c) Pengembangan produk pangan, yaitu minuman bayam wortel nanas (Batelnas), minuman okra madu jahe (The Kraduu), dodol jahe wijen (Dojawi), dan dodol jahe wortel (Dojawo); dan d) Pengembangan sistem pemasaran produk pangan dan kompos yang dilakukan secara online.

\section{METODE PELAKSANAAN KEGIATAN}

\section{Lokasi Kegiatan}

Diversifikasi produk olahan pangan hasil aplikasi vertikultur tanaman sayuran dilaksanakan di RW 10, Kelurahan Tengah, Kecamatan Kramat Jati, Jakarta Timur. Khalayak sasaran dari kegiatan diversifikasi produk olahan pangan hasil aplikasi vertikultur tanaman sayuran adalah masyarakat Kelurahan Tengah bekerja sama dengan salah satu tokoh masyarakat yang berada di Kelurahan Tengah (H Ramin sebagai mitra 1 dan Ibu PKK yang diwakili oleh Ibu Titi sebagai mitra 2).

\section{Bahan dan Alat}

Alat yang digunakan selama kegiatan berupa satu set alat vertikultur, satu set alat pengolahan pangan (kompor, panci, wadah, blender, saringan, pengaduk, pisau, gelas ukur dan timbangan, dan lain-lain), serta satu paket teknologi online (akun facebook, instagram, serta blog). Bahan yang digunakan selama kegiatan berupa bayam, wortel, nanas, madu, jahe, okra, dan lain-lain.

\section{Metode Pelaksanaan Kegiatan}

Berdasarkan permasalahan yang telah diuraikan sebelumnya dan kesepakatan antara tim pengabdian dengan mitra, maka solusi yang ditawarkan untuk mengatasi permasalahan yang ada adalah sebagai berikut:

- Proses membangun motivasi sumber daya. Proses ini dimaksudkan agar sumber daya yang akan diberdayakan memiliki keinginan dalam penghijauan lingkungan, memajukan usaha melalui diversifikasi olahan pangan. Adanya keikutsertaan secara aktif akan memberikan dampak pada perbaikan kesejahteraan mereka. Khalayak sasaran dari kegiatan ini bekerjasama dengan salah satu tokoh masyarakat yang berada di Kelurahan Tengah (H Ramin/mitra 1 dan Ibu Titi/mitra 2). Kelurahan Tengah terdiri dari 10 RW, dengan masing-masing RW mengirimkan tiga orang, sehingga terdapat 30 orang yang berkontribusi dalam mendukung kegiatan diversifikasi produk olahan pangan hasil aplikasi vertikultur tanaman sayuran.

- Pemanfaatan tanaman pangan keluarga. Pada tahap ini akan dilakukan pemanfaatan untuk penghijauan lingkungan dan sebagai bahan baku diversifikasi beberapa produk olahan pangan. Tanaman pangan yang digunakan, yaitu bayam, okra, wortel, jahe, dan tanaman lainnya.

- Program pengembangan pemasaran dan usaha. Apabila program telah berjalan dengan baik, maka diperlukan dukungan akses untuk pengembangan usaha. Hal ini dilakukan dengan mengembangkan pasar melalui sistem online.

- Proses pendampingan, bertujuan untuk menjaga komitmen, keberlangsungan program dan membangun kerja sama tim yang baik.

\section{Prosedur Kerja}

Upaya mendukung realisasi metode yang ditawarkan, maka prosedur kerja yang dilaksanakan adalah 1) Melaksanakan kegiatan pelatihan/pendampingan motivasi sumber daya; 2) Melaksanakan pelatihan/pendampingan paket teknologi penghijauan (menggunakan pipa talang air berbentuk persegi panjang yang disusun 
secara vertikal (verikultur)); 3) Melaksanakan pengolahan pangan berupa minuman bayam wortel nanas (Batelnas), minuman okra madu jahe (The Kraduu), dodol jahe wijen (Dojawi), dan dodol jahe wortel (Dojawo); dan 4) Melaksanakan pemberdayaan mitra melalui kegiatan pelatihan/pendampingan berupa teknik pemasaran produk pangan yang dihasilkan secara digital.

Metode Pengumpulan, Pengolahan, dan Analisis Data

Metode pengambilan dan analisis data yang digunakan dalam kegiatan ini adalah metode deskriptif. Data dan informasi yang terkumpul diolah dan dianalisis secara kualitatif. Kegiatan yang telah dilaksanakan ini dilakukan melalui observasi, wawancara, pelatihan, dan bimbingan teknis, serta dokumentasi.

\section{HASIL DAN PEMBAHASAN}

Diversifikasi produk olahan pangan hasil aplikasi vertikultur tanaman sayuran telah dillaksanakan di RW 10, Kelurahan Tengah, Kecamatan Kramat Jati, Jakarta Timur. Kegiatan yang telah dilaksanakan adalah pertemuan dan koordinasi; sosialisasi pada mitra dan masyarakat; pelatihan dan pendampingan paket teknologi penghijauan menggunakan teknologi vertikultur; bimbingan teknis pengolahan produk makanan dan minuman berbasis sayuran, buah, dan rempah; pelatihan teknik pemasaran produk secara digital; dan proses pendampingan serta evaluasi.

\section{Pertemuan dan Koordinasi}

Kegiatan pertama yang telah dilakukan berupa pertemuan dan koordinasi dengan khalayak sasaran (mitra dan masyarakat sekitar). Hasil pertemuan dan koordinasi tersebut adalah khalayak sasaran bersedia mendukung dan berkontribusi langsung dalam kegiatan pemanfaatan tanaman pangan pekarangan sebagai media penghijauan dan produk olahan pangan bernilai ekonomis. Selain itu, ibu-ibu PKK Kelurahan Tengah juga bersedia berpartisipasi aktif dalam program ini. Kelurahan Tengah terdiri dari 10 RW, dengan masing-masing RW mengirimkan tiga orang, sehingga terdapat 30 orang yang berkontribusi dalam mendukung kegiatan diversifikasi produk olahan pangan hasil aplikasi vertikultur tanaman sayuran. Kegiatan perte- muan dan koordinasi dengan khalayak sasaran dapat dilihat pada Gambar 1.

\section{Sosialisasi pada Mitra dan Masyarakat}

Kegiatan kedua yang telah dilaksanakan berupa sosialisasi ke mitra dan masyarakat sekitar tentang pentingnya menanam tanaman pangan keluarga berupa sayur (ditinjau dari segi nutrisi), tentang rencana kegiatan olahan produk pangan, serta tentang pentingnya penghijauan di lingkungan sekitar. Hasil pertemuan dan sosialisasi pendampingan ini adalah meningkatnya kembali dan motivasi dan partisipasi khalayak sasaran. Kegiatan sosialisasi dapat dilihat pada Gambar 2.

\section{Pelatihan dan Pendampingan Paket Teknologi Penghijauan dengan Teknologi Vertikultur}

Kegiatan selanjutnya yang telah dilaksanakan berupa pelatihan/pendampingan paket teknologi penghijauan menggunakan teknologi vertikultur yang telah dimodifikasi. Pelatihan ini bermanfaat untuk mengenalkan dan mempraktikkan sistem pertanian vertikultur, sehingga dapat memotivasi khalayak sasaran untuk mengaplikasikannya di rumah dan lingkungan tempat tinggal. Vertikultur adalah sistem tanam di dalam pot yang disusun/dirakit horizontal dan vertikal atau

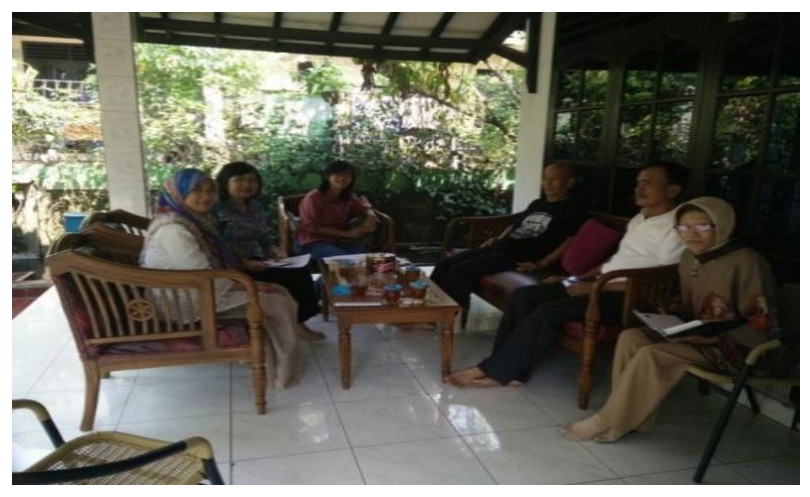

Gambar 1 Kegiatan pertemuan dan koordinasi dengan khalayak sasaran.

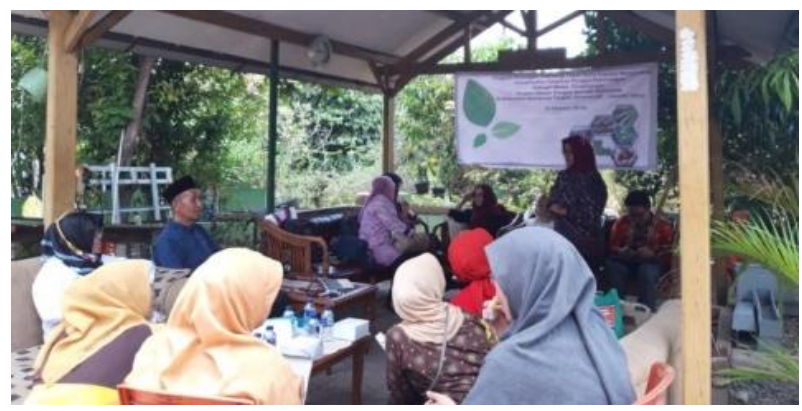

Gambar 2 Sosialisasi ke mitra dan masyarakat sekitar tentang pentingnya menanam sayur. 
bertingkat pada lahan terbatas atau halaman rumah, sehingga tidak memerlukan lahan yang luas dan dapat dibuat di manapun di sekitar rumah dengan pemeliharaan yang sangat sederhana (Hasyim \& Mirajuddin 2013). Teknologi pertanian vertikultur ini sangat sederhana, mudah diterapkan, serta tidak memerlukan keahlian yang khusus, pola pertanian vertikultur ini memberikan harapan yang cukup menjanjikan bila ditekuni dengan baik. Belum berkembangnya pertanian vertikultur di Wilayah Jakarta Timur disebabkan berbagai faktor di antaranya kurangnya informasi tentang pertanian vertikultur. Vertikultur tidak sekadar menanam tanaman secara vertikal, namun dapat memberikan keindahan suasana hijau di rumah dan hasil tanamannya dapat dimanfaatkan oleh keluarga dan masyarakat sekitar untuk meningkatkan perekonomian dengan menjual tanaman pangan organik tersebut. Pemilihan teknologi ini dikarenakan dapat dengan mudah diaplikasikan pada lahan yang terbatas, dapat dipindahkan dengan mudah karena tanaman diletakkan dalam wadah tertentu, serta mempermudah monitoring/pemeliharaan tanaman. Pelatihan yang telah dilaksanakan menjadikan mitra beserta masyarakat RW 10 Kelurahan Tengah bersedia dan bersemangat untuk mengaplikasikan teknologi-teknologi tersebut, karena mereka memiliki lahan terbatas di sekitar rumahnya.

\section{Bimbingan Teknis Pengolahan Produk Makanan dan Minuman}

Rangkaian kegiatan selanjutnya dari kegiatan ini adalah berupa bimbingan teknis pengolahan produk makanan dan minuman berbasis sayuran, buah, dan rempah. Dalam kegiatan ini mitra dan masyarakat dilatih untuk mengolah beberapa bahan pangan menjadi berbagai jenis produk makanan dan minuman, yakni berupa minuman bayam, wortel, dan nanas (Batelnas), minuman okra, madu, dan jahe (The Kraduu), makanan dodol, jahe, dan wijen (Dojawi), serta makanan dodol, jahe, dan wortel (Dojawo).

Alur proses produksi dan rincian biaya produksi Batelnas terlihat pada Tabel 1 dan Gambar 3. Batelnas harga kemasan sebesar Rp 1.000, harga kemasan ditambah bahan sebesar Rp 9.646, dan harga jual sebesar Rp 10.00012.000. Alur proses produksi dan rincian biaya produksi The Kraduu terlihat pada Tabel 2 dan Gambar 4. The Kraduu harga kemasan sebesar Rp 1.000, harga kemasan ditambah bahan sebesar Rp 15.186, harga jual sebesar Rp 16.000-18.000. Alur proses produksi dan rincian biaya produksi
Tabel 1 Rincian biaya produksi minuman bayam wortel nanas (Batelnas)

\begin{tabular}{lrrr}
\hline \multicolumn{1}{c}{ Bahan } & $\begin{array}{c}\text { Jumlah } \\
\text { yang } \\
\text { dipakai }\end{array}$ & $\begin{array}{c}\text { Harga } \\
\text { per unit } \\
\text { (Rp) }\end{array}$ & $\begin{array}{c}\text { Total } \\
\text { harga } \\
\text { (Rp) }\end{array}$ \\
\hline Daun bayam bersih & $50 \mathrm{~g}$ & 15.000 & 750 \\
Wortel import & $50 \mathrm{~g}$ & 20.000 & 4.000 \\
Nanas & $200 \mathrm{~g}$ & 9.000 & 1.800 \\
Gula pasir & $100 \mathrm{~g}$ & 14.000 & 1.400 \\
Air & $900 \mathrm{~mL}$ & 5.800 & 696 \\
\hline Total & & & 8.646 \\
\hline
\end{tabular}

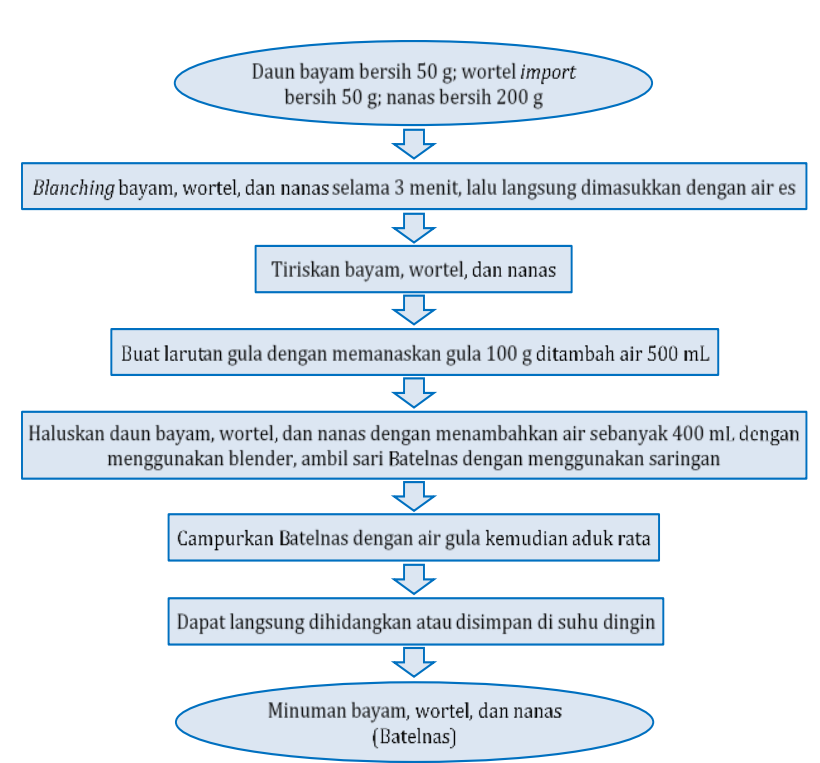

Gambar 3 Alur proses produksi produksi Batelnas.

Tabel 2 Rincian biaya produksi minuman okra, madu, dan jahe (The Kraduu)

\begin{tabular}{lrrr}
\hline Bahan & $\begin{array}{c}\text { Jumlah yang } \\
\text { dipakai }\end{array}$ & $\begin{array}{c}\text { Harga per } \\
\text { unit (Rp) }\end{array}$ & $\begin{array}{c}\text { Total } \\
\text { harga (Rp) }\end{array}$ \\
\hline Okra & $176 \mathrm{~g}$ & 40.000 & 7.040 \\
Madu & $150 \mathrm{~g}$ & 20.000 & 6.000 \\
Jahe & $50 \mathrm{~g}$ & 9.000 & 450 \\
Air & $1,5 \mathrm{~L}$ & 5.800 & 696 \\
\hline Total & & & 14.186 \\
\hline
\end{tabular}

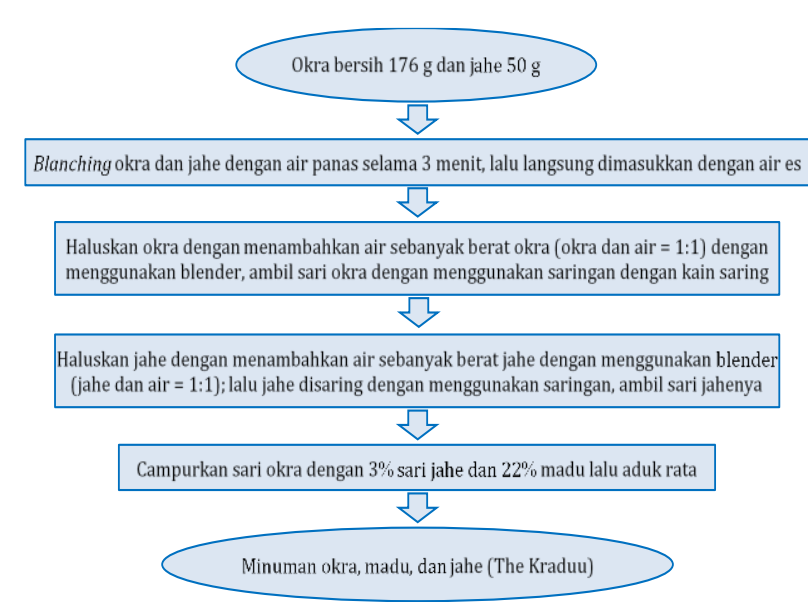

Gambar 4 Alur proses produksi The Kraduu. 
Dojawi terlihat pada Tabel 3 dan Gambar 5 . Dojawi harga kemasan sebesar Rp 1.200, jumlah dodol per satu resep 25 buah, harga per buah sebesar Rp 14.240 : 25 = Rp 569,60, harga modal (10 buah dodol ditambah harga kemasan) sebesar Rp 6.896, harga jual sebear Rp 10.00013.000. Alur proses produksi dan rincian biaya produksi Dojawo terlihat pada Tabel 4 dan Gambar 6. Dojawo harga kemasan sebesar Rp 1.200, jumlah dodol per satu resep 25 buah, harga per buah sebesar Rp $14.160: 25=\mathrm{Rp}$ 566,40 , harga modal (10 buah dodol ditambah harga kemasan) sebesar Rp 6.864, harga jual sebesar Rp 10.000-13.000.

Kegiatan bimbingan teknis pengolahan produk makanan dan minuman berbasis sayuran, buah, dan rempah bertujuan untuk meningkatkan pengetahuan, wawasan, dan keterampilan

Tabel 3 Rincian biaya produksi dodol jahe wijen (Dojawi)

\begin{tabular}{lrrr}
\hline \multicolumn{1}{c}{ Bahan } & $\begin{array}{c}\text { Jumlah } \\
\text { yang } \\
\text { dipakai }\end{array}$ & $\begin{array}{c}\text { Harga } \\
\text { per unit } \\
(\mathrm{Rp})\end{array}$ & $\begin{array}{c}\text { Total } \\
\text { harga } \\
(\mathrm{Rp})\end{array}$ \\
\hline Tepung ketan & $100 \mathrm{~g}$ & 22.000 & 2.200 \\
Tepung maizena & $10 \mathrm{~g}$ & 4.000 & 400 \\
Jahe & $20 \mathrm{~g}$ & 20.000 & 2.000 \\
Gula pasir & $100 \mathrm{~g}$ & 14.000 & 1.400 \\
Garam & $1 \mathrm{sdt}^{*}$ & 5.000 & 50 \\
Kayu manis bubuk & $0,5 \mathrm{sdt}^{*}$ & 15.000 & 1.500 \\
Margarin & $20 \mathrm{~g}$ & 22.000 & 440 \\
Biji Wijen & $50 \mathrm{~g}$ & 50.000 & 3.750 \\
Gas & $10 \mathrm{~g}$ & 25.000 & 2.500 \\
\hline Total & & & 14.240 \\
\hline
\end{tabular}

Keterangan: ${ }^{*}=$ sendok teh

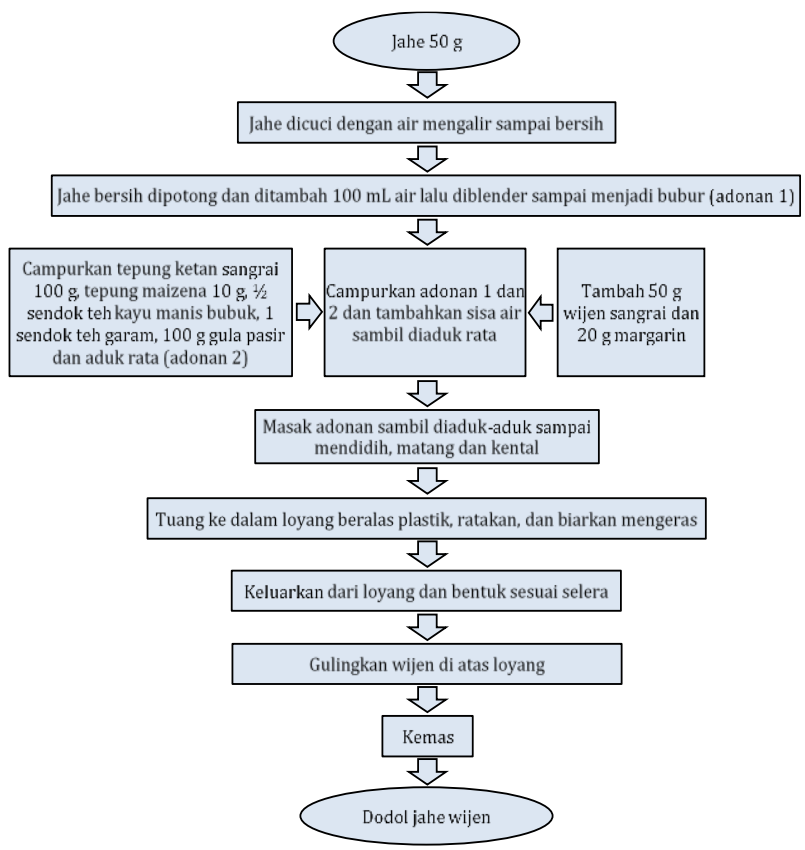

Gambar 5 Alur proses produksi Dojawi. peserta tentang pengolahan pangan terutama minuman yang beragam, bergizi, sehat, serta bernilai ekonomis. Manfaat dari kegiatan dan teknologi yang telah diajarkan adalah 1) Memberikan dan meningkatkan informasi, pengetahuan, wawasan, serta keterampilan kepada khalayak sasaran dan 2) Produk olahan bernilai ekonomis yang dapat menjadi sumber pendapatan rumah tangga bagi khalayak sasaran. Harga jual dari produk olahan yang dilatih kepada khalayak sasaran cukup bersaing di pasaran, dimana harga jual produk olahan minuman berupa Batelnas dan The Kraduu memiliki kisaran harga masingmasing sebesar Rp 10.000-12.000 dan Rp 15.000-18.000. Harga tersebut cukup bersaing dengan produk minuman sari buah sejenis di pasaran yang berada pada kisaran harga sebesar Rp 10.000-30.000. Produk olahan makanan yang

Tabel 4 Rincian biaya produksi dodol, jahe, dan wortel (Dojawo)

\begin{tabular}{lrrr}
\hline \multicolumn{1}{c}{ Bahan } & $\begin{array}{c}\text { Jumlah } \\
\text { yang } \\
\text { dipakai }\end{array}$ & $\begin{array}{c}\text { Harga } \\
\text { per unit } \\
(\mathrm{Rp})\end{array}$ & $\begin{array}{c}\text { Total } \\
\text { harga } \\
(\mathrm{Rp})\end{array}$ \\
\hline Tepung ketan & $100 \mathrm{~g}$ & 22.000 & 2.200 \\
Wortel & $40 \mathrm{~g}$ & 17.000 & 680 \\
Jahe & $10 \mathrm{~g}$ & 20.000 & 2.000 \\
Gula pasir & $160 \mathrm{~g}$ & 14.000 & 2.240 \\
Garam & $1 \mathrm{sdt}^{*}$ & 5.000 & 50 \\
Kayu manis bubuk & $0,5 \mathrm{sdt}^{*}$ & 15.000 & 1.500 \\
Margarin & $20 \mathrm{~g}$ & 22.000 & 440 \\
Santan & $120 \mathrm{~mL}$ & 8.500 & 2.550 \\
Gas & $10 \mathrm{~g}$ & 25.000 & 2.500 \\
\hline Total & & & 14.240
\end{tabular}

Keterangan: ${ }^{*}=$ sendok teh

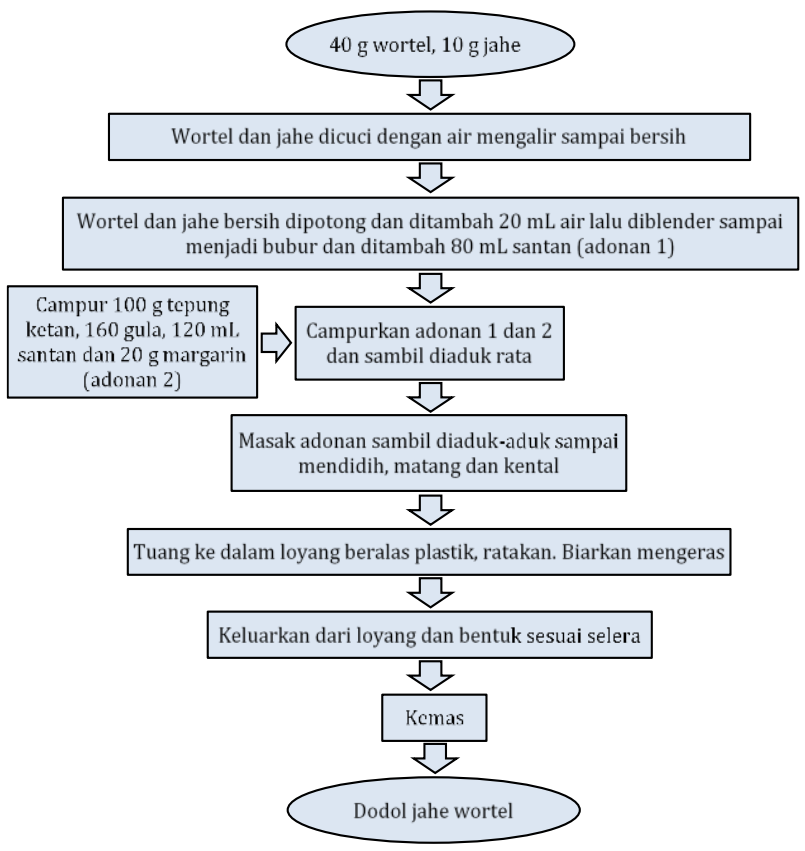

Gambar 6 Alur proses produksi Dojawo. 
dilatih berupa Dojawi dan Dojawo juga dianggap mampu bersaing di pasaran. Harga jual Dojawi dan Dojawo berada pada kisaran Rp 10.00013.000/kemasan, sedangkan dodol pada umumnya dijual di pasaran dengan harga $\mathrm{Rp} 12.000-$ 18.000/kemasan; dan 3) Kegiatan bimbingan teknis pengolahan produk makanan dan minuman berbasis sayuran, buah, dan rempah dapat meningkatkan kemandirian ekonomi masyarakat, sehingga secara tidak langsung dapat meningkatkan kembali minat dan partisipasi khalayak sasaran untuk berperan aktif dalam kegiatan pemanfaatan tanaman pangan pekarangan sebagai media penghijauan produk olahan pangan.

Novitasari (2011) dalam Ashari et al. (2016) menyatakan bahwa pekarangan sebagai tata guna lahan yang merupakan sistem produksi bahan pangan tambahan dalam skala kecil untuk dan oleh anggota keluarga rumah tangga dan merupakan ekosistem tajuk berlapis. Beberpa tahun terakhir program pemanfaatan lahan pekarangan cukup insentif dilakukan, dengan nama kawasan rumah pangan lestari (KRPL). KRPL merupakan suatu himpunan rumah yang mampu mewujudkan kemandirian pangan keluarga melalui pemanfaatan tanaman pekarangan (Saptana 2006). Prinsip utama pengembangan pekarangan keluarga melalui model Kawasan Rumah Pangan Lestari (m-KRPL) adalah mendukung upaya ketahanan dan kemandirian pangan keluarga, diversifikasi pangan berbasis sumber daya lokal, konservasi tanaman pangan untuk masa depan, dan peningkatan kesejahteraan keluarga (Ferizal 2012). Terdapat empat tahapan pelaksanaan, yaitu penumbuhan model, replikasi model, pengembangan usaha yang memerlukan kemitraan dengan unit lain, serta tahap keberlanjutan usaha (Badan Penelitian dan Pengembangan Pertanian 2013). Hasil pertanian dan budi daya pangan suatu daerah merupakan suatu aset ekonomi, budaya, dan kesehatan masyarakat. Oleh karena itu, pelaksanaan workshop dan bimbingan teknis produk olahan pangan dapat bermanfaat dalam mewujudkan ketahanan pangan rumah tangga, terwujudnya diversifikasi pangan, dan apabila terus dilakukan secara terusmenerus dapat berkontribusi dalam terjaminnya keamanan pangan bagi daerah tersebut. Bimbingan teknis pengolahan produk makanan dan minuman berbasis sayuran, buah, dan rempah dapat dilihat pada Gambar 7.

\section{Pelatihan Teknik Pemasaran Produk Secara Digital}

Kegiatan terakhir yang dilakukan adalah pelatihan teknik pemasaran produk secara digital. Pelatihan ini bertujuan untuk meningkatkan pengetahuan, wawasan, dan keterampilan peserta tentang pemasaran secara digital/online, sehingga khalayak sasaran mampu memasarkan produknya secara luas dan mudah. Kemajuan teknologi informasi yang semakin mendunia menyebabkan perubahan perilaku konsumen dalam membeli produk. Konsumen pada saat ini menuntut layanan permasaran online melalui internet yang mudah, cepat dan dapat diakses dari mana saja dan kapan saja tanpa terikat jam kerja secara global. Pada dasarnya konsumen selalu menginginkan kemudahan bila ingin membeli suatu produk (Wandanaya 2012). Sistem pemasaran digital merupakan salah satu media pemasaran yang saat ini sedang banyak diminati oleh masyarakat untuk medukung berbagai kegiatan yang dilakukan. Mereka sedikit demi sedikit mulai meninggalkan model pemasaran konvensional/tradisional beralih ke pemasaran modern, yaitu digital marketing. Dengan digital marketing komunikasi dan transaksi dapat dilakukan setiap waktu/real time dan bisa mengglobal atau mendunia (Pradiani 2017). Kegiatan pelatihan/pendampingan teknik pemasaran produk secara digital pada Gambar 8.
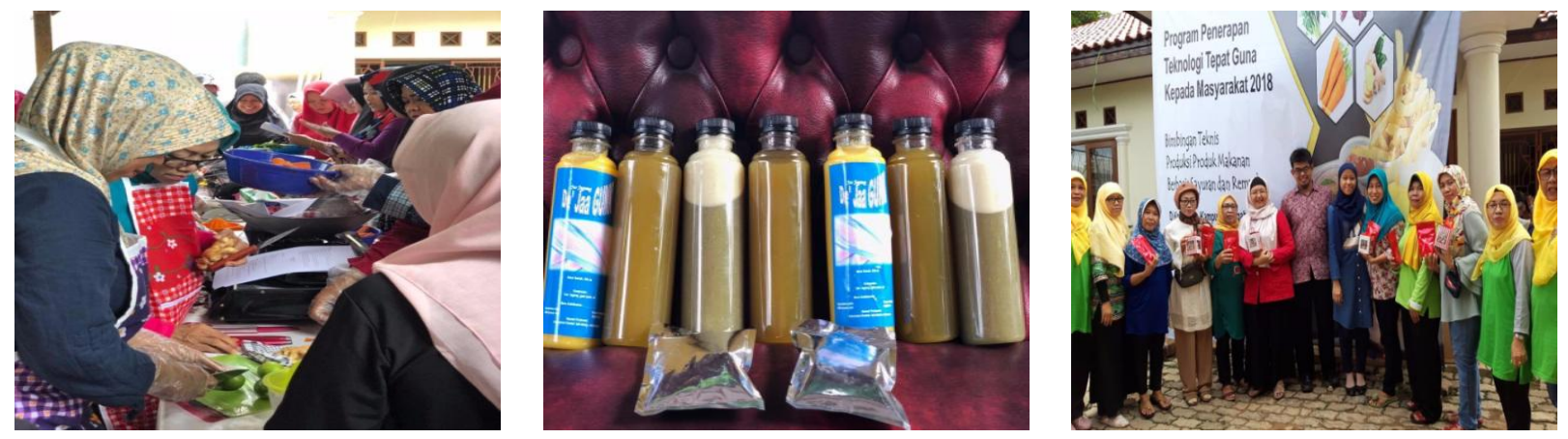

Gambar 7 Bimbingan teknis pengolahan produk makanan dan minuman berbasis sayuran, buah dan rempah. 

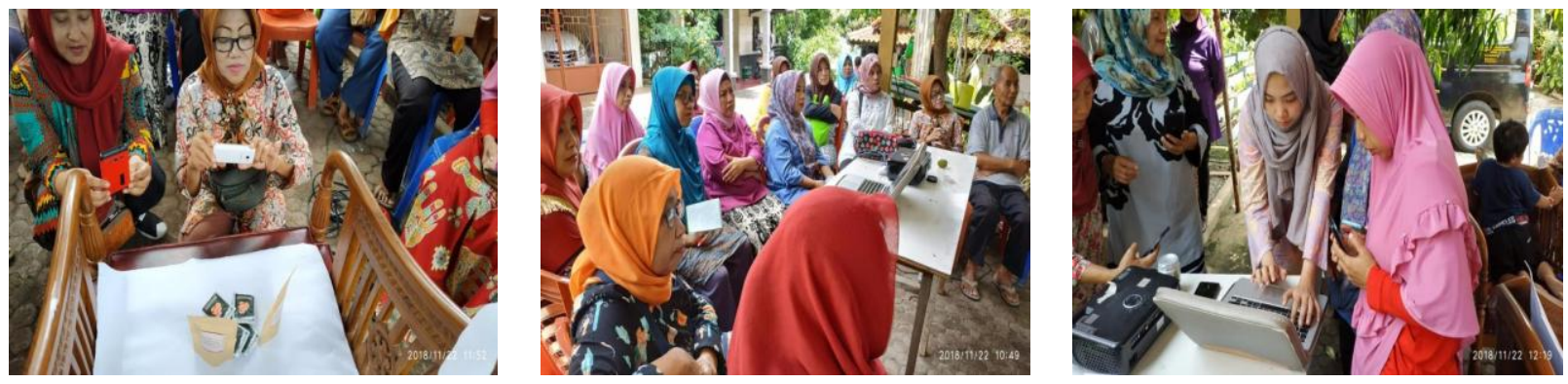

Gambar 8 Pelatihan/pendampingan teknik pemasaran produk secara digital.

Pelaksanaan kegiatan diversifikasi produk olahan pangan hasil aplikasi vertikultur tanaman sayuran di Kelurahan Tengah, Kramat Jati, diperoleh wawasan bahwa khalayak sasaran tertarik untuk menggunakan teknik pemasaran produk secara digital dan memanfaatkan media sosial secara optimal, namun mereka menghadapi beberapa kendala. Beberapa kendala yang dihadapi adalah kurangnya pemahaman mengenai pentingnya digital marketing, kurangnya pengetahuan mengenai teknologi informasi dan komunikasi serta cara-cara penggunaan dan pemanfaatan media sosial yang baik, tidak sabar ingin segera mendapat hasil, serta kurangnya pemahaman untuk menciptakan postingan yang menarik. Kendala-kendala tersebut diatasi oleh tim pengabdian kepada masyarakat dengan memberikan pelatihan berupa langkah-langkah yang harus dilakukan oleh mitra dalam memasarkan produknya secara digital dengan membuat dan mengelola akun media sosial. Langkah-langkah yang telah dilakukan, yaitu a) Membuat akun media sosial untuk usaha yang terpisah dengan akun pribadi; b) Membuat nama akun yang sederhana, mudah diingat, menjelaskan tentang usahanya, dan memiliki nama yang sama dengan platform media sosial lain yang digunakan, dan c) Me-posting secara berkala dan rutin, disesuaikan dengan timing yang tepat. Dalam upaya memasarkan produk secara digital, perlu memerhatikan waktu yang ideal untuk berpromosi. Ada waktu-waktu tertentu di mana traffic internet sangat tinggi, yaitu saat begitu banyak orang mengakses internet. Dengan mengetahui kapan saja waktu terbaik untuk menuliskan atau posting sesuatu di akun jejaring sosial, maka semakin banyak akun yang dapat menjangkau posting-an tersebut; d) Membuat tanda pagar (hashtag) unik yang mencirikan usaha kita dan gunakan itu di setiap post; dan e) Menjawab segala pertanyaan yang ditanyakan oleh follower untuk menandakan bahwa akun aktif.

\section{Proses Pendampingan dan Evaluasi}

Proses pendampingan dilakukan untuk menjaga komitmen, keberlangsungan program, dan membangun kerja sama tim yang baik. Proses pendampingan dilakukan dua minggu setelah pelaksanaan masing-masing kegiatan, dan proses evaluasi dilakukan satu bulan setelah seluruh kegiatan dilaksanakan.

Kegiatan diversifikasi produk olahan pangan hasil aplikasi vertikultur tanaman sayuran di Kelurahan Kampung, Kramat Jati yang telah dilaksanakan dapat menjadi prime-mover sektor ekonomi, sosial, dan budaya bagi khalayak sasaran (mitra dan masyarakat). kegiatan ini menghasilkan beberapa produk olahan pangan bernilai ekonomis serta dapat dikomersialkan oleh khalayak sasaran sehingga dapat memberikan keuntungan finansial. Kegiatan ini mampu menjadi mesin penggerak kemajuan ekonomi yang tangguh bagi khalayak sasaran apabila dilakukan secara kontinu. Bimbingan teknis dan workshop yang telah dilakukan dapat meningkatkan nilai tambah dari bahan baku yang selama ini kurang diminati menjadi produk yang bernilai ekonomis. Selain itu, kegiatan ini juga dapat memberikan dampak positif dengan terbukanya peluang usaha pengolahan produk olahan pangan dan meningkatkan penyerapan tenaga kerja, yang akan berdampak peningkatan pertumbuhan ekonomi di lingkungan khalayak sasaran.

Pelatihan bimbingan teknis pengolahan pangan yang diberikan kepada khalayak sasaran didasarkan pada bahan baku khas yang banyak terdapat di lingkungan sekitar mereka menghasilkan produk olahan serta branding yang unik dan khas, dan dapat dijadikan identitas dan ciri khas daerah yang bersangkutan. Saat ini, produk olahan pangan terutama pangan tradisional dijadikan komoditas gaya hidup yang dikemas dengan menonjolkan identitas lokal sehingga menarik untuk dipasarkan dalam industri kuliner. Produk olahan pangan/makanan khas 
suatu daerah dengan strategi branding yang unik akan menjadi daya tarik tersendiri bagi wisatawan, sehingga daerah khalayak sasaran akan lebih dikenal. Mitra beserta warga Kelurahan Tengah yang terdiri dari $10 \mathrm{RW}$ melalui kegiatan ini dapat sering bertemu sehingga dapat meningkatan interaksi sosial yang bermanfaat bagi lingkungan. Interaksi sosial yang baik dapat memperkuat jaringan sosial masyarakat dan kelembagaan yang baik pula. Sistem kelembagaan suatu masyarakat yang rapuh akan melemahkan keberhasilan pelaksanaan program pengem-bangan teknologi, inovasi, investasi, dan tidak tercapainya kemajuan ekonomi yang tangguh (Elizabeth 2015). Transformasi dan penguatan jaringan kelembagaan yang berbasis sumber daya pertanian dengan melakukan pemanfaatan tanaman pangan pekarangan sebagai media penghijauan dan produk olahan pangan bernilai ekonomis menjadi salah satu upaya penting dan faktor penunjang dalam pengembangan agro-industri bahan pangan di Kelurahan Tengah, Kramat Jati.

Kegiatan diversifikasi produk olahan pangan hasil aplikasi vertikultur tanaman sayuran di Kelurahan Tengah, Kramat Jati dalam pelaksanaanya terdapat beberapa kendala di antaranya: a) Terdapat kendala dalam menemukan jadwal yang tepat untuk penentuan jadwal pelaksanaan kegiatan, hal ini dikarenakan padatnya jadwal kegiatan yang sudah terjadwal rutin setiap minggunya (pembekalan lansia, arisan, kegiatan PKK, dan kegiatan insidental dari kelurahan ataupun kecamatan) baik yang diikuti mitra 1 maupun mitra 2, sehingga banyak kegiatan yang bentrok; dan b) Terbatasnya peserta dalam kegiatan, hal ini dikarenakan warga yang berperan aktif dalam kegiatan adalah warga yang sudah lansia, sedangkan untuk warga dengan usia produktif sulit untuk bisa ikut serta dalam kegiatan-kegiatan kemasyarakatan dikarenakan kesibukan dalam bekerja. Kendala-kendala tersebut telah ditindak lanjuti dengan a) Melakukan komunikasi yang cukup intens dan efektif terhadap semua mitra, agar setiap minggunya mendapatkan jadwal kegiatan pasti mitra sehingga dapat menentukan jadwal yang tepat dalam penyelenggaraan kegiatan dan b) Menggandeng pihak-pihak yang berwenang dan berpengaruh di daerah Kramat Jati untuk membantu mengajak warga Kramat Jati dengan usia produktif dapat mengikuti kegiatan.

\section{SIMPULAN}

Permasalahan yang dihadapi oleh mitra dapat dilaksanakan melalui proses memotivasi diri dengan dibantu oleh pelaksana kegiatan pengabdian masyarakat yang bertindak sebagai fasilitator. Selain itu, kegiatan yang dilakukan pada program ini berupa paket teknologi penghijauan menggunakan teknologi vertikultur yang telah dimodifikasi, pengolahan pangan berupa minuman bayam, wortel, dan nanas (Batelnas), minuman okra, madu, dan jahe (The Kraduu), makanan dodol, jahe, dan wijen (Dojawi), serta makanan dodol, jahe, dan wortel (Dojawo) menjadi prioritas utama dalam produksi, untuk mencapai tujuan sebagai solusi atas permasalahan tersebut dilakukan pendekatan melalui kegiatan pelatihan.

Pelatihan/pendampingan penghijauan menggunakan sistem vertikultur ini bermanfaat untuk mengenalkan dan mempraktikkan sistem pertanian vertikultur yang dapat dengan mudah diaplikasikan pada lahan yang terbatas, dapat dipindahkan dengan mudah karena tanaman diletakkan dalam wadah tertentu, serta mempermudah monitoring/pemeliharaan tanaman. Pelatihan lain berupa bimbingan teknis pengolahan produk makanan dan minuman berbasis sayuran, buah, dan rempah bertujuan untuk meningkatkan pengetahuan, wawasan, dan keterampilan peserta tentang pengolahan pangan terutama minuman yang beragam, bergizi, sehat, serta bernilai ekonomi. Pelatihan ini berisi materi pengolahan produk-produk olahan menggunakan teknologi yang sederhana sehingga dapat mudah diaplikasikan oleh khalayak sasaran dan industri kecil. Pelatihan diharapkan dapat menjadi sumber pendapatan rumah tangga bagi khalayak sasaran. Produkproduk olahan pangan tersebut dikomersialkan dengan teknik pemasaran yang tepat, salah satunya dengan teknik pemasaran produk secara digital.

Pada kegiatan diversifikasi produk olahan pangan hasil aplikasi vertikultur tanaman sayuran di Kelurahan Tengah, Kramat Jati, juga memberikan pelatihan pemberdayaan mitra melalui kegiatan pelatihan pendampingan berupa teknik pemasaran produk pangan yang dihasilkan secara digital. Teknik pemasaran secara digital ini memiliki kelebihan, yaitu tidak memerlukan modal yang besar sehingga dapat 
dengan mudah diaplikasikan oleh khalayak sasaran, serta jangkauan produk akan lebih luas dan dapat mudah diakses oleh konsumen dimanapun dan kapanpun, sehingga kontinuitas dapat dipertahankan.

\section{UCAPAN TERIMA KASIH}

Kami mengucapkan terima kasih yang sebesar-besarnya kepada Kementerian Riset Teknologi dan Pendidikan Tinggi yang telah membantu membiayai kegiatan melalui program Penerapan Teknologi Tepat Guna (PPTTG) pada Tahun 2018, Ibu Wiryanti Sukamdani, Camat Kramat Jati beserta jajaran, Lurah Kampung Tengah beserta jajaran, serta kepada masyarakat RW 10, Kelurahan Kampung Tengah, Kecamatan Kramat Jati, Jakarta Timur.

\section{DAFTAR PUSTAKA}

Ashari, Saptana, Purwantini TB. 2012. Potensi dan prospek pemanfaatan lahan pekarangan untuk mendukung ketahanan pangan. Forum Penelitian Agro Ekonomi. 30(1): 13-30. https://doi.org/10.21082/fae.v30n1.2012.13 $-30$

Badan Penelitian dan Pengembangan Pertanian. 2013. Petunjuk Pelaksanaan Pengembangan Model Kawasan Rumah Pangan Lestari dan Sinergi Program TA 2013.

Elizabeth R. 2015. Pengembangan Agroindustri Bahan Pangan untuk Peningkatan Nilai Tambah melalui Transformasi Kelembagaan di Pedesaan. Iptek Tanaman Pangan. 5(1): 102-112.

Ferizal M. 2012. Pengembangan Model Kawasan Rumah Pangan Lestari (m-KRPL) di Provinsi Aceh. Laporan Akhir Tahun Balai Pengkajian Teknologi Pertanian Aceh. Aceh (ID): Balai
Besar Pengkajian dan Pengembangan Teknologi Pertanian Badan Penelitian dan Pengembangan Pertanian Kementrian Pertanian.

Hasyim M, Mirajuddin M. 2013. Pendampingan Pembuatan media veltikultur untuk penanaman Tumbuhan Obat dalam Pemaksimalan Pekarangan Rumah. Asian Journal of Innovation and Entrepreneurship. 2(2): 82-87.

Mardiyanto A. 2009. Perencanaan Lanskap Pekarangan Dengan Sistem Pertanian Terpadu. [Skripsi]. Bogor (ID): Institut Pertanian Bogor.

Mardiharini M. 2011. Model Kawasan Rumah Pangan Lestari dan Pengembangannya ke Seluruh Provinsi di Indoensia. Warta Penelitian dan Pengembangan Pertanian. 33(6): 3-5.

Novitasari E. 2011. Studi Budi daya Tanaman Pangan di Pekarangan sebagai Sumber Ketahanan Pangan Keluarga (studi Kasus di Desa Ampel Gading Kecamatan Tirtoyudo Kabupaten Malang). [Skripsi]. Malang (ID): Universitas Brawijaya. Malang.

Pradiani T. 2017. Pengaruh Sistem Pemasaran Digital Marketing Terhadap Peningkatan Volume Penjualan Hasil Industri Rumahan. Jibeka. 11(2): 46-53. https://doi.org/ 10.32812/jibeka.v11i2.45

Saptana, Sunarsih, Indraningsih KS. 2006. Mewujudkan keunggulan komparatif menjadi keunggulan kompetitif melalui pengembangan kemitraan usaha hortikultura. Forum Penelitian Agro Ekonomi. 24(1): 61-76. https://doi.org/10.21082/fae.v24n1.2006.61 $-76$

Wandanaya AB. 2012. Pengaruh Pemasaran Online Terhadap Keputusan Pembelian Produk. CCIT Journal. 5(2): 174-185. 